\title{
THROMBOTIC THROMBOCYTOPENIC PURPURA: ETIOPATHOGENESIS, DIAGNOSTICS AND BASIC PRINCIPLES OF TREATMENT
}

\author{
Zeljko Todorovic ${ }^{1}$, Milena Jovanovic ${ }^{2}$, Dusan Todorovic ${ }^{1}$, Dejan Petrovic ${ }^{2}$, Predrag Djurdjevic ${ }^{3}$ \\ ${ }^{1}$ Faculty of Medical Sciences, University of Kragujevac, Serbia \\ ${ }^{2}$ Center of Nephrology and Dialysis, Clinic for Urology and Nephrology, Clinical Center "Kragujevac", Serbia \\ ${ }^{3}$ Clinic for Hematology, Clinical Center "Kragujevac", Serbia
}

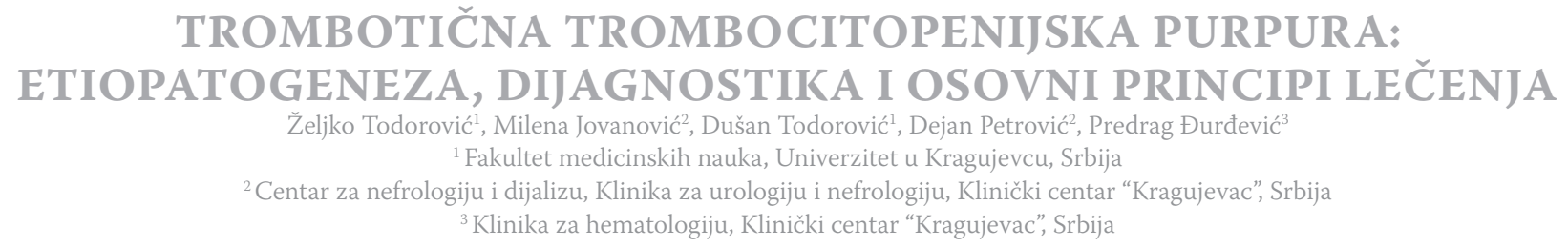

Received / Primljen: 19. 12. 2015.

Accepted / Prihvaćen: 22. 02. 2016

\begin{abstract}
Thrombotic thrombocytopenic purpura (TTP) is a clinical syndrome that manifests with thrombocytopenia, microangiopathic haemolytic anaemia and symptoms and signs of kidney and brain damage, but it rarely involves other organs. The main pathophysiological cause of TTP is diminished metalloproteinase ADAMTS13 activity; the main function of ADAMTS13 is to degrade large multimers of the von Willebrand factor. Diminished activity of ADAMTS13 is caused either by a genetic mutation in the gene that codes ADAMTS13 (congenital TTP) or by antibodies that block ADAMTS13 enzyme activity or accelerate the degradation of ADAMTS13 (acquired TTP). Clinically, TTP presents most frequently with signs and symptoms of brain and kidney damage with concomitant haemorrhagic syndrome. TTP is suspected when a patient presents with a low platelet count, microangiopathic haemolytic anaemia (negative Coombs tests, low haptoglobine concentration, increased serum concentration of indirect bilirubin and lactate dehydrogenase, increased number of schysocytes in peripheral blood) and the typical clinical presentation. A definitive diagnose can be made only by measuring the ADAMTS13 activity. The differential diagnosis in such cases includes both typical and atypical haemolytic uremic syndrome, disseminated intravascular coagulation, HELLP syndrome in pregnant women and other thrombotic microangiopathies. The first line therapy for TTP is plasma exchange. In patients with acquired TTP, in addition to plasma exchange, immunosuppressive medications are used (corticosteroids and rituximab). In patients with hereditary TTP, the administration of fresh frozen plasma is sometimes required.
\end{abstract}

Keywords: TTP, ADAMTS13, plasmapheresis, rituximab

\section{SAŽETAK}

Trombotična trombocitopenijska purpura (TTP) je klinički sindrom koji se odlikuje trombocitopenijom, mikroangiopatskom hemoliznom anemijom $i$ simptomima $i$ znacima oštećenja bubrega i mozga, ređe drugih organa. Glavni patofiziološki mehanizam nastanka TTP-a je smanjena aktivnost metaloproteinaze ADAMTS13 čija je osnovna uloga razgradnja velikih multimera von Willebrand-ovog faktora. Smanjena aktivnost metaloproteinaze ADAMTS13 nastaje usled mutacije u genu za ADAMTS13 (urodeni TTP) ili usled nastanka antitela koja blokiraju ili antitela koja ubrzavaju razgradnju ADAMTS13 (stečeni TTP). Klinički se ispoljava znacima i simptomima oštećenja mozga $i$ bubrega, kao i slikom hemoragijskog sindroma. Sumnja na TTP se postavlja na osnovu smanjenog broj trombocita, mikroangiopatske hemolizne anemije (negativan Coombs-ov test, smanjena koncentracija haptoglobina, povećana koncentracija indirektnog bilirubina i laktat dehidrogenaze u serumu, povećan broj šizocita u razmazu periferne krvi) $i$ tipične kliničke slike, a definitivna dijagnoza se postavlja merenjem aktivnosti ADAMTS13. U diferencijalnoj dijagnozi treba isključiti tipični i atipični hemolitičko-uremijski sindrom, diseminovanu inravaskularnu koagulaciju, HELLP sindrom kod trudnica, kao i druge trombotične mikroangiopatije. Prva linija terapije kod kod bolesnika sa TTP-om je plazmafereza. Kod bolesnika sa stečenim oblikom TTP-a, uz plazmaferezu se koriste i imunosupresivni lekovi (kortikosteroidi i rituksimab), a kod bolesnika sa urođenim oblikom TTP-a povremena supstitucija sa sveže smznutom plazmom.

Ključne reči: TTP, ADAMTS13, plazmafereza, rituksimab

\section{ABBREVIATIONS}

ADAMTS13 - disintegrin and metalloprotease with thrombospondin type 1 repeats, member 13

HIV - human immunodeficiency virus

HUS - haemolytic uremic syndrome

FRETS - fluorescence resonance energy transfer ELISA - enzyme-linked immunosorbent assay
TTP - thrombotic thrombocytopenic purpura

ULvWF - ultralarge von Willebrand factor multimers vWF - Von Willebrand factor

PAGE - polyacrylamide gel electrophoresis

SDS - sodium dodecyl sulphate

HIT - heparin induced thrombocytopenia 


\section{INTRODUCTION}

Thrombotic thrombocytopenic purpura (TTP) is a rare clinical syndrome characterized by the formation of disseminated platelet aggregates in small blood vessels and consequent microangiopathic haemolytic anaemia. The aggregated platelets can cause ischaemia, hypoxia and abnormal function of the affected organs. The classical clinical pentad of TTP consists of microangiopathic haemolytic anaemia, thrombocytopenia, fluctuating neurological signs, impaired renal function and fever. However, patients with TTP usually do not present with all of these clinical signs (approximately $35 \%$ of the patients did not present with signs of neurological dysfunction) (1-3). The renal function in patients suffering from TTP can vary greatly, ranging from acute renal failure to fully preserved renal function, but the most common consequence is a moderate and transient decrease in renal function (4). The thrombocytopenia is usually severe $\left(10-30 \times 10^{9} / 1\right)$ due to the sequestration of platelets in microvascular thrombi. The haemolytic anaemia is a consequence of mechanical damage to the red blood cells as they pass through the narrowed microcirculation (1-3).

\section{AETIOLOGY AND PATHOGENESIS OF TTP}

The main pathogenetic mechanism of TTP is decreased activity of matrix metalloproteinase ADAMTS13 (a disintegrin and metalloprotease with thrombospondin type 1 repeats, member 13). The main function of ADAMTS13 is splitting the ultra-large von Willebrand factor multimers (ULvWF) into smaller fragments $(2,5)$.

The von Willebrand factor (vWF) is a protein synthesized mostly by endothelial cells and, in a smaller proportion, by megakaryocytes (6). Its role is essential for initiating primary haemostasis. After blood vessels experience endothelial damage, vWF connects to subendothelial collagen via the A3 domain and enables the adherence of platelets through its A1 domain that binds GPIb $\alpha / \mathrm{IX} / \mathrm{V}$ platelet's receptor. The globular form hides the ULvWF A2 domain that binds metalloproteinase ADAMTS13. After it is transformed into a string-like form, the A2 domain is revealed and binds to ADAMTS13, which cleaves the ULvWF into monomers (Figure 1). The second part of the vWF is then processed in the small blood vessels where the large shear forces unfolds the globular ULvWF. The third place where ULvWF degradation occurs is in damaged blood vessels, where it binds to the subendothelial collagen via the A3 domain, and the ULvWF unfolds and reveals the $\mathrm{A} 2$ and $\mathrm{A} 1$ domains $(3,10)$.

The nomenclature of TTP is not standardized, but the term "TTP" is typically restricted to cases with severe deficiency of ADAMTS13 activity (<10\%) (11). Based on the pathogenetic mechanism leading to reduced activity of ADAMTS13, TTP is divided into congenital and acquired (3).
The majority of patients suffer from the acquired, antibody mediated form of TTP (approximately 95\% of all cases) (12). Commonly, these antibodies block the primary epitope of ADAMTS13 and inhibit its proteolytic function. However, in approximately $10-15 \%$ cases of acquired TTP, the patients have non-inhibitory antibodies, and the ADAMTS13 deficiency is a result of an increased clearance of ADAMTS13-antibody complexes. The inhibitory antibodies are IgG isotypes, predominantly of the IgG4 subclass. The IgG4 subclass is associated with more frequent relapses of the disease. The antibodies may also be from the IgG1, IgG2, IgG3 subclasses, as well as from isotype $\operatorname{IgA}(13,14)$.

The aetiological cause of acquired TTP is often unknown, and that form of TTP is categorized as primary (or idiopathic). In the smaller number of patients with immune dysregulation due to other diseases, the term secondary acquired TTP is used (5). In the literature, there are a few reported cases of enterohaemorrhagic Escherichia coli infection with concomitant thrombotic microangiopathy that were treated as classical haemolytic uremic syndrome (HUS), but the subsequent measurement of the activity of metalloprotease ADAMTS13 revealed its reduced activity $(<10 \%)(15)$. The impact of human immunodeficiency virus (HIV) as an aetiological factor of TTP remains controversial. Different studies have shown different prevalences of HIV infection in patients with TTP $(16,17)$. Certain medications have been associated with the development of TTP. Ticlopidine increases the risk of TTP by 200-500-fold $(18,19)$. On the other hand, drugs such as quinine, calcineurin inhibitors and certain chemotherapeutics can cause thrombotic microangiopathy, but they are not associated with significantly decreased activity of ADAMTS13.

The correlation between TTP and pregnancy is complex. Pregnancy decreases the level of ADAMTS13 by approximately $30 \%(20)$. In women with reduced ADAMTS13 activity, pregnancy can trigger the acute onset of TTP. In the postpartum period, the immune tolerance present during pregnancy is terminated, and an acceleration of the existing autoimmune response to ADAMTS13 may occur. According to a regional English TTP registry, $5 \%$ of all TTP episodes are related to pregnancy (21). Jiang and colleagues explored the connection between TTP and pregnancy complications in 10 women with acquired TTP in the Oklahoma TTP-HUS Registry. These 10 women had a total of 16 pregnancies. The outcomes of the 16 pregnancies were as follows: 2 pregnancies complicated with the acute onset of TTP, 2 with preeclampsia, 2 ended due to pregnancy loss, and 10 without complications (22). These data suggest that TTP is one of the risk factors for pregnancy complications.

Hereditary TTP is the least common form of the disease, and it occurs as a result of mutations in the ADAMTS13 gene that are located on the long arm of chromosome 9. Heterozygous carriers of ADAMTS13 mutations usually have slightly reduced ADAMTS13 activity in the serum, and a small percentage suffer from TTP. Homozy- 

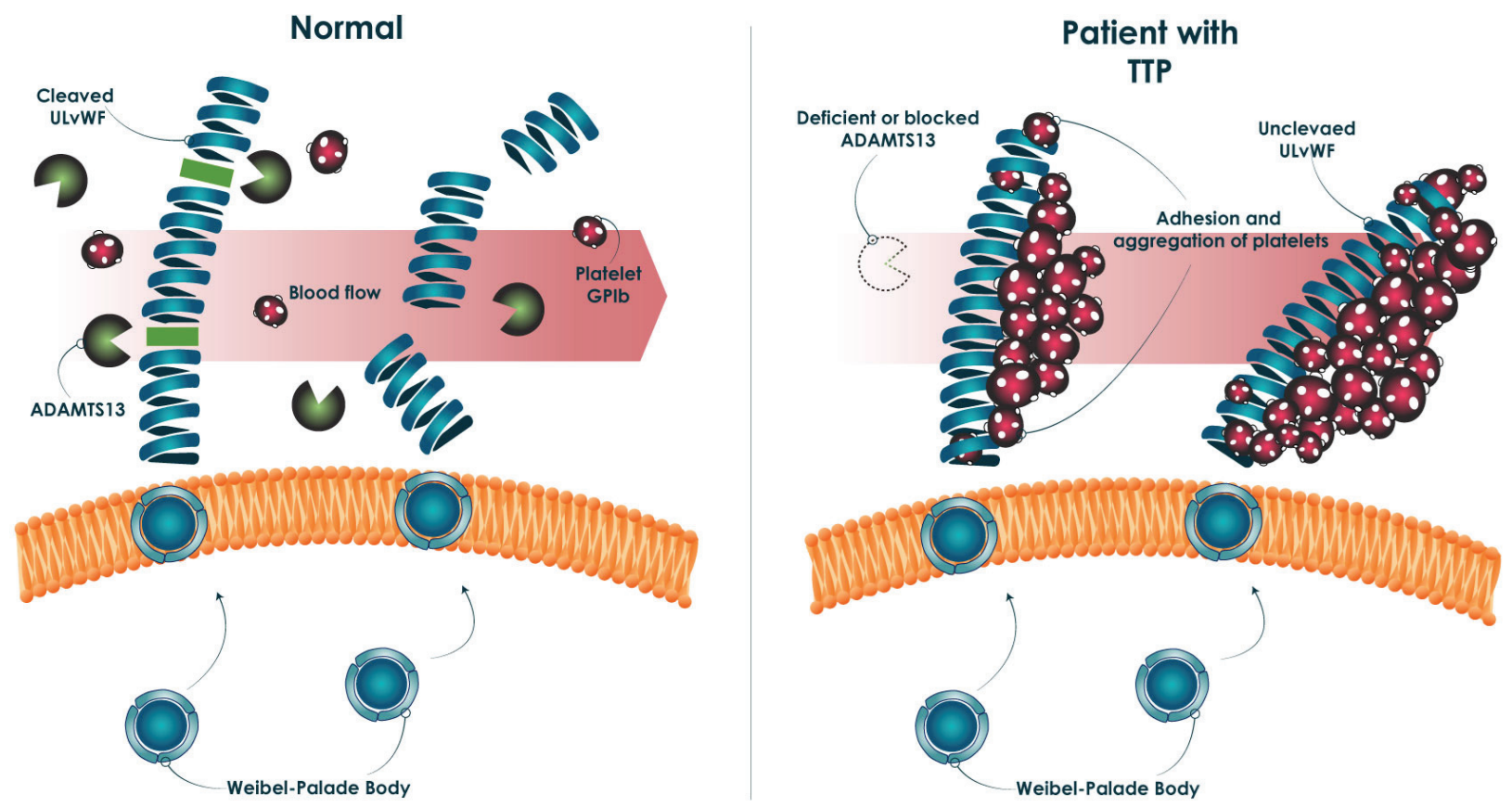

Figure 1. Production and cleavage of ULvWF by ADAMTS13 in a normal subject and in a patient with TTP (original) Abbreviations: ULvWF - ultralarge von Willebrand factor multimers; TTP - thrombotic thrombocytopenic purpura.

gous carriers of mutations are quite rare; they occur frequently in families with consanguinity. The activity of $\mathrm{AD}$ AMTS13 is significantly reduced in homozygous carriers $(<5 \%)(3,23)$. There are approximately 140 different mutations of the ADAMTS13 gene, and the most frequently mentioned mutations in the literature are the single base insertion 4143insA in exon 29 and the missense mutation Arg1060Trp in exon $24(24,25)$. About half of the patients with hereditary TTP first exhibited signs and symptoms of the disease during the first year of life. In the other half of TTP patients, the disease occurred between the ages of 20 and 40 years old. Only a few patients had their first attack of TTP after the age of 60 (5).

\section{CLINICAL MANIFESTATION OF TTP}

The TTP clinical pentad consisting of thrombocytopenia, microangiopathic haemolytic anaemia, neurological signs and symptoms, renal impairment and fever is not specific to TTP and, in the majority of patients, is not completely manifested. The clinical presentation depends on the organ affected by microvascular ischaemia. Microvascular ischaemia of the central nervous system manifests with headache, somnolence, focal neurological disturbances, convulsions and coma. Renal impairment is usually manifested as intermittent proteinuria and haematuria, and only rarely as acute renal failure. Other, less common clinical manifestations of TTP include nausea, vomiting, abdominal pain, disorders of heart rhythm, congestive heart failure, myocardial ischaemia and, in rare cases, sudden cardiac death $(1-5,26$,
27). Bruises and petechial bleeding in the skin, epistaxis, menorrhagia, haematuria or gastrointestinal haemorrhage can arise, but bleeding complication are generally rare despite severe thrombocytopenia, even during the placement of central venous catheters $(1-5,28)$

In patients with congenital TTP hyperbilirubinemia, thrombocytopenia and microangiopathic haemolytic anaemia are often identified immediately after birth or in the neonatal period. The frequency of congenital TTP exacerbations varies from several days to several years. Factors that can lead to exacerbation of TTP are fever, infection, diarrhoea, trauma, surgery or pregnancy $(1-5,17)$.

Thrombocytopenia, due to sequestration of platelets in microthrombi in small blood vessels, is usually severe $\left(10-30 \times 10^{9} / 1\right)$. Microangiopathic haemolytic anaemia is obligatory in TTP patients. Laboratory parameters that indicate this type of anaemia are decreased serum levels of haemoglobin (80-100 g/l) and haptoglobine, increased serum levels of indirect bilirubin and lactate dehydrogenase (LDH), the presence of fragmented parts of red blood cells (schistocytes) in the peripheral blood and a negative Coombs tests (Figure 2). Normal serum levels of liver enzymes exclude HELLP syndrome (haemolysis, elevated liver enzymes, low platelet count). The parameters of haemostasis (thrombin time, activated partial thromboplastin time and fibrinogen) are usually normal, which helps differentiate TTP from disseminated intravascular coagulation (1-5).

The diagnosis of TTP should be suspected in the presence of the clinical features and laboratory results described above. It is necessary to measure ADAMTS13 enzyme activity for a definite diagnosis of TTP. The term "TTP" is 


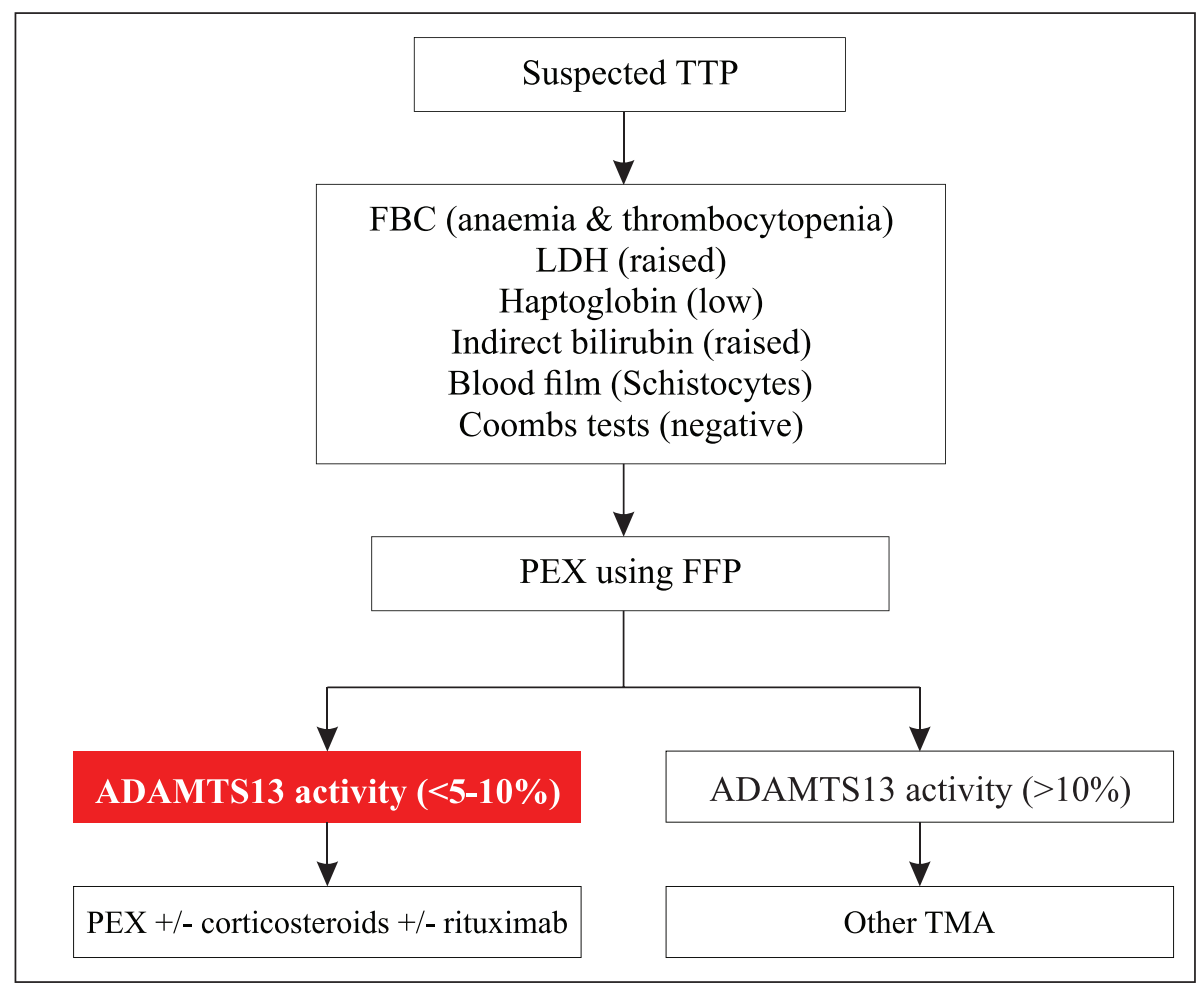

Figure 2. Algorithm for the diagnosis and treatment of TTP (original)

Abbreviations: TTP - thrombotic thrombocytopenic purpura; FBC - full blood count; PEX - plasma exchange; FFP - fresh frozen plasma; TMA - thrombotic microangiopathy

customarily used for thrombotic microangiopathy with measured ADAMTS13 activity less than 5-10\% (depending on the type of test). An earlier study demonstrated that ADAMTS13 plasma activity of less than 5-10\% appeared to be specific for TTP and helps to differentiate TTP from other thrombotic microangiopathies with a similar clinical appearance (11) (Figure 2). In addition, the serum concentration of the vWF antigen and concentrations of inhibitory and non-inhibitory antibodies to ADAMTS13 can be measured. Based on these tests results, specialists can distinguish congenital from acquired $\operatorname{TTP}(5,29)$.

\section{ADAMTS13 ASSAYS}

The plasma assays that measure ADAMTS13 activity are based on the cleavage of plasma-derived or recombinant vWF multimers. Depending on whether the assay measures the substrates of cleavage or the cleavage products themselves, the assays are either direct or indirect measurements, respectively $(30,31)$.

The direct assays measure the cleavage products of vWF macromolecules, vWF A2 domain, or the small peptides GST-vWF-73 or FRETS-73. Agarose or polyacrylamide gel electrophoresis (PAGE), western blotting, and fluorescence resonance energy transfer (FRETS) techniques are used for the measurement of the cleavage products. There are several direct assays: SDS (sodium dodecyl sulphate) agarose gel electrophoresis and western blotting, SDS-
PAGE and western blotting and FRETS Assay $(30,31)$. The FRETS assay uses the truncated synthetic 73-amino-acid vWF peptide as a substrate for measuring ADAMTS13 activity. This assay is rapid and more sensitive and specific than the others (32).

The indirect assays measure the residual substrate (i.e., vWF) or its disappearance. They include the collagenbinding assay, ristocetin-induced aggregation and the enzyme-linked immunosorbent (ELISA) assays. In the collagen-binding assay, after the incubation of purified vWF with patient's plasma in the presence of $1.5 \mathrm{M}$ urea, and $10 \mathrm{mM} \mathrm{BaCl}_{2}$ for 16 to 24 hours, the amount of residual vWF is determined by its binding to human collagen type III. The bound VWF is quantified by the peroxidase-conjugated anti-vWF immunoglobulin G (IgG) on an ELISA plate, followed by a densitometry measurement $(33,34)$. The ristocetin-induced aggregation assay is similar to the collagen binding assay, but the residual vWF is measured by ristocetin-induced platelet aggregation using a platelet aggregometer (35). In the ELISA assay, a recombinant vWF fragment is immobilized onto an ELISA plate using an antibody to a tag the vWF. After the incubation of the patient's plasma with an immobilized substrate, an antibody to another tag detects the residual substrate. The photolytic activity of ADAMTS13 is inversely proportional to the residual substrate concentration. This type of assay is relatively simple and sensitive (36).

The above described assays can detect inhibitory antibodies but the FRETS assay appears to be the most sensi- 
tive. An ELISA assay along with western blotting using the recombinant ADAMTS13 as an antigen can also be used to detect both inhibitory and non-inhibitory autoantibodies (37).

\section{DIFFERENTIAL DIAGNOSIS OF TTP}

In clinical practice, TTP should be differed from both typical and atypical HUS. HUS is a clinical syndrome that is characterized by thrombocytopenia, microangiopathic haemolytic anaemia, small vessel microthrombosis and acute kidney injury $(2,38)$. Typical HUS is the result of endothelial cell damage, which is caused by the Shiga toxin of the Escherichia coli serotype O157:H7 (2, 38). Atypical HUS is the result of dysfunction of alternative complement pathway regulating proteins, including complement factors I, complement factors B, complement factors $\mathrm{H}$, membrane cofactor protein and complement C3 component $(2,38)$. To exclude both typical and atypical HUS, the following analyses should be done: microbiological examination of the stool (stool culture for Escherichia coli O157:H7 serotype), anti-lipopolysaccharide antibodies and PCR (polymerase chain reaction) for Shiga toxin, and testing of the alternative complement pathway activity $(2,38)$.

For the differential diagnosis of TTP, a few more entities should be considered such as disseminated intravascular coagulation, an acquired coagulation disorder which is characterized by a small vessel microthrombosis and secondary haemorrhagic syndrome, often observed in systemic infections and malignancy (38). Antiphospholipid syndrome, especially its rare clinical manifestation called catastrophic antiphospholipid syndrome, can make a differential diagnosis with TTP difficult because this clinical form of antiphospholipid syndrome presents with multi-organ failure due to thrombosis and also with thrombocytopenia and microangiopathic anaemia (39). Occasionally, heparin induced thrombocytopenia (HIT) can mimic TTP because of the organ failure due to thrombosis and consequent thrombocytopenia, but a normal platelet count before the initiation of heparin therapy in HIT and confirmation of the antibodies against the complex of heparin and platelet factor 4 distinguish those two disorders (40). HELLP syndrome should also be considered in pregnant women with thrombocytopenia and haemolytic anaemia. HELLP affects $0.5 \%$ to $0.9 \%$ of all pregnancies and develops in $10 \%$ of patients with preeclampsia. The diagnostic criteria for HELLP syndrome include microangiopathic haemolytic anaemia, a lactate dehydrogenase level $>600 \mathrm{U} / \mathrm{ml}$, increased aspartate aminotransferase $(\geq 40-70 \mathrm{U} / \mathrm{ml}$, depending on the series), and thrombocytopenia (platelet count $<$ $100 \times 10^{9} / 1-150 \times 10^{9} / 1$, depending on the series). Termination of pregnancy does not induce remission of TTP, unlike HELLP syndrome, so it is crucial to differentiate those two diagnoses (41).

\section{MANAGEMENT OF TTP}

TTP is an acute, life threatening disease that demands immediate treatment in highly specialized facilities that can perform plasmapheresis.

Plasmapheresis (plasma exchange) is the first-line treatment of patients with acquired and congenital TTP. This process removes the antibodies of ADAMTS13 in patients with acquired TTP. Fresh frozen plasma is used as a substitution for removed plasma during plasmapheresis (Figure 2). Fresh frozen plasma contains metalloproteinase ADAMTS13 and renews its concentration in the serum. Plasmapheresis should be administered within 24 hours of the clinical onset of TTP, and it should be administered daily for 3 consecutive days; during plasmapheresis, 1-1.5 of the plasma volume should be exchanged. In patients who present with neurological deficit and signs of cardiac ischaemia, two plasmapheresis treatments per day are necessary during the first three days of the disease. Daily plasmapheresis should be continued two days after the platelet count gets higher than $150 \times 10^{9} / 1$, and then it should be stopped $(29,42,43)$.

During the initial treatment of acquired TTP, in addition to plasmapheresis, immunosuppressive drugs such as corticosteroids and anti-CD20 antibody (rituximab) can be used.

Faster immunosuppression and reduction of anti-ADAMTS13 antibodies is achieved with the administration of corticosteroids. There are no studies that demonstrate the advantage of any corticosteroid in particular, but methylprednisolone is the most commonly used agent at a dose of $10 \mathrm{mg} / \mathrm{kg}$ per day. Studies have shown that higher doses of corticosteroids are more efficient than standard ones (1 $\mathrm{mg} / \mathrm{kg}$ per day) (44). Methylprednisolone is administered daily for three days, right after plasmapheresis, so that only a minimal amount of the drug is removed (29).

Studies have shown that treatment of acquired TTP with rituximab lowers the number of necessary plasmapheresis sessions, shortens the duration of the hospitalization and diminishes the relapse risk. In one observational study, 40 rituximab-treated patients were compared to 40 historical controls who did not receive rituximab and were treated with conventional therapy (plasmapheresis+corticosteroi ds). The remission rate among the trial group was 93\%, and among the controls, it was $95 \%$. When the patients who were admitted to an intensive care unit were excluded, this study showed that the rituximab-treated patients had hospitalizations that were 7 days shorter. There was a statistically significance difference in the percent of relapses and the time to relapse between those two groups. Only 10 percent of the trial cases relapsed, at a median of 27 months, compared to a $57 \%$ relapse rate among the historical controls, at a median of 18 months (45). There are no recommendations for the dosage and frequency of administration of rituximab. In the previously mentioned multi-centre study, rituximab was administered at a dosage of $375 \mathrm{mg} / \mathrm{m}^{2}$, once a week, for 4 weeks in a row. In patients who exhibited a slower response, rituximab treatment was extended to 8 weeks (45). 
In addition to its role for the initial treatment of TTP, rituximab is also used for the treatment of refractory and relapsed TTP. An observational study that compared 21 patients with refractory TTP treated with rituximab and 53 historical controls treated with conventional therapy reported that all the patients treated with rituximab experienced platelet count recovery within 35 days compared to only $78 \%$ of the control patients (46). The results from 5 other similar studies showed that $83-100 \%$ rituximabtreated patients achieved complete remission (47-52). The relapse rates after rituximab treatment ranged from $0 \%$ with a median follow-up of 10 months (47) to 33\% with a median follow-up of 73 months (52). Patients who are refractory to plasmapheresis, corticosteroids and rituximab may benefit from bortezomib administration (53-55).

Finally, rituximab can be used for prophylactic treatment of patient who experienced a previous acute episode of TTP when their ADAMTS13 activity is $<10 \%$, even without clinical signs and symptoms. Several studies have demonstrated that prophylactic treatment with rituximab prolonged relapse-free survival $(56,57)$.

Rituximab is removed by plasmapheresis, so it should be administered right after a plasma exchange session. During the period of plasmapheresis treatment, rituximab can be used more frequently (every 3-4 days), to keep the serum concentration at a high level (29). Given its high efficacy and safety, rituximab can be recommended as the initial treatment for acquired TTP, treatment of refractory and relapsed TTP and prophylactic treatment.

Although the treatment of TTP has improved significantly in recent years, there is still room for improvement. One of new medications used for the treatment of TTP is recombinant metalloproteinase ADAMTS13. In addition to compensating for the deficiency of ADAMTS13 in patients with congenital TTP, recombinant ADAMTS13 is also resistant to antibody inhibition in most patients with acquired TTP (58). Caplacizumab is a potential new drug for the treatment of TTP. Caplacizumab is an anti vWfantibody that has shown high efficacy in the treatment of TTP in animal models (59). Caplacizumab binds to the $\mathrm{N}$-terminal end of the A1 region of vWf and inhibits the interaction between vWf and platelets (60).

\section{CONCLUSION}

TTP has long been known as a life threatening disease. In the last decade, our understanding of the basic biochemistry of the VWF-ADAMTS13 axis has provided valuable insights into the pathogenesis of TTP. The better understanding of pathogenesis of TTP has led to the development of new therapeutic strategies. In addition, assays that measure ADAMTS13 activity can help differentiate TTP from other thrombotic microangiopathies with a similar clinical appearance. Although the mortality associated with TTP has been appreciably reduced, much remains to be learned, especially about how to treat patients who are refractory to the standard therapies.

\section{Acknowledgments}

The authors would like to express their deepest gratitude to the Serbian Ministry of Science and Technological Development for their Grants N0175014 and III41010, which were used as one of the sources to financially support the study.

\section{REFERENCES}

1. Petrović D. Akutno oštećenje bubrega: etiologija, dijagnostika i lečenje. Medicinska Istraživanja. 2011;45(3):7-13.

2. Said A, Haddad RY, Stein R, Lerma EV. Thrombotic thrombocytopenic purpura. Dis Mon. 2014;60(10):500-4.

3. Crawley JT, Scully MA. Thrombotic thrombocytopenic purpura: basic pathophysiology and therapeutic strategies. Hematology Am Soc Hematol Educ Program. 2013;2013(1):292-9.

4. Barbour T, Johnson S, Cohney S, Hughes P. Thrombotic microangiopathy and associated renal disorders. Nephrol Dial Transplant. 2012;27(7):2673-85.

5. Kremer Hovinga JA, Lämmle B. Role of ADAMTS13 in the pathogenesis, diagnosis, and treatment of thrombotic thrombocytopenic purpura. Hematology Am Soc Hematol Educ Program. 2012;2012(1):610-6.

6. Giblin JP, Hewlett LJ, Hannah MJ. Basal secretion of von Willebrand factor from human endothelial cells. Blood. 2008;112(4):957-964.

7. Springer TA. Biology and physics of von Willebrand factor concatamers. J Thromb Haemost. 2011;9(Suppl 1):130-143.

8. Zhou YF, Eng ET, Zhu J, et al. Sequence and structure relationships within von Willebrand factor. Blood. 2012;120(2):449-458.

9. Zhang X, Halvorsen K, Zhang CZ, et al. Mechanoenzymatic cleavage of the ultralarge vascular protein von Willebrand factor. Science. 2009;324(5932):1330-1334.

10. Siedlecki CA, Lestini BJ, Kottke-Marchant KK, et al. Shear-dependent changes in the three-dimensional structure of human von Willebrand factor. Blood. 1996;88(8):2939-2950.

11. Bianchi V, Robles R, Alberio L, et al. Von Willebrand factor-cleaving protease (ADAMTS13) in thrombocytopenic disorders: a severely deficient activity is specific for thrombotic thrombocytopenic purpura. Blood. 2002;100:710-13.

12. Scully M, Yarranton H, Liesner R, et al. Regional UK TTP registry: correlation with laboratory ADAMTS 13 analysis and clinical features. Br J Haematol. 2008;142(5):819-826.

13. Ferrari S, Mudde GC, Rieger M, et al. IgG subclass distribution of anti-ADAMTS13 antibodies in patients with acquired thrombotic thrombocytopenic purpura. J Thromb Haemost. 2009;7(10):1703-1710.

14. Ferrari S, Scheiflinger F, Rieger M, et al. Prognostic value of 614 American Society of Hematology anti- 
ADAMTS 13 antibody features (Ig isotype, titer, and inhibitory effect) in a cohort of 35 adult French patients undergoing a first episode of thrombotic microangiopathy with undetectable ADAMTS 13 activity. Blood. 2007;109(7):2815-2822.

15. Hunt BJ, La"mmle B, Nevard CH, et al. von Willebrand factor-cleaving protease in childhood diarrhoeaassociated haemolytic uraemic syndrome. Thromb Haemost. 2001;85(6):975-978.

16. Terrell DR, Williams LA, Vesely SK, et al. The incidence of thrombotic thrombocytopenic purpurahemolytic uremic syndrome: all patients, idiopathic patients, and patients with severe ADAMTS-13 deficiency. J.Thromb.Haemost 2005;3(7):1432-1436.

17. Tsai HM. The kidney in thrombotic thrombocytopenic purpura. Minerva Med. 2007;98(6):731-47.

18. Bennett CL, Davidson CJ, Raisch DW, et al. Thrombotic thrombocytopenic purpura associated with ticlopidine in the setting of coronary artery stents and stroke prevention. Arch.Intern.Med 1999;159(21):2524-2528.

19. Tsai HM, Rice L, Sarode R, et al. Antibody inhibitors to von Willebrand factor metalloproteinase and increased binding of von Willebrand factor to platelets in ticlopidineassociated thrombotic thrombocytopenic purpura. Ann Intern.Med 2000;132(10):794-799.

20. Lattuada A, Rossi E, Calzarossa C, et al. Mild to moderate reduction of a von Willebrand factor cleaving protease (ADAMTS-13) in pregnant women with HELLP microangiopathic syndrome. Haematologica 2003;88(9):1029-1034.

21. Scully M, Yarranton H, Liesner R, et al. Regional UK TTP registry: correlation with laboratory ADAMTS 13 analysis and clinical features. Br J Haematol 2008;142(5):819-826.

22. Jiang Y, McIntosh JJ, Reese JA, et al. Pregnancy outcomes following recovery from acquired thrombotic thrombocytopenic purpura. Blood. 2014;123(11):1674-80.

23. Levy GG, Nichols WC, Lian EC, et al. Mutations in a member of the ADAMTS gene family cause thrombotic thrombocytopenic purpura. Nature. 2001;413(6855):488-494.

24. Schneppenheim R, Kremer Hovinga JA, Becker T, et al. A common origin of the 4143insA ADAMTS13 mutation. Thromb Haemost. 2006;96(1):3-6.

25. Camilleri RS, Cohen H, Mackie IJ, et al. Prevalence of the ADAMTS-13 missense mutation R1060W in late onset adult thrombotic thrombocytopenic purpura. J Thromb Haemost. 2008;6(2):331-338.

26. Takimoto T, Nakao M, Nakajo T, et al. Acute myocardial infarction as the initial thrombotic event of thrombotic thrombocytopenic purpura. Blood Coagul Fibrinolysis. 2016 Jan 11. [Epub ahead of print]

27. Yamamoto K, Hattori Y, Shimada K, et al. Sudden death associated with myocardial damage caused by microthrombi in a patient with thrombotic thrombocytopenic purpura. Rinsho Ketsueki. 2015;56(11):2336-40.
28. Duffy SM, Coyle TE. Platelet transfusions and bleeding complications associated with plasma exchange catheter placement in patients with presumed thrombotic thrombocytopenic purpura. J Clin Apher. 2013;28(5):356-8.

29. Blombery P, Scully M. Management of thrombotic thrombocytopenic purpura: current perspectives. J Blood Med. 2014;5:15-23.

30. Shelat SG, Ai J, Zheng XL. Molecular biology of ADAMTS13 and diagnostic utility of ADAMTS13 proteolytic activity and inhibitor assays. Semin Thromb Hemost. 2005;31(6):659-72.

31. Franchini M, Mannucci PM. Advantages and limits of ADAMTS13 testing in thrombotic thrombocytopenic purpura. Blood Transfus. 2008;6(3):127-35.

32. Kokame K, Nobe Y, Kokubo Y, et al. FRETS-VWF73, a first fluorogenic substrate for ADAMTS13 assay. Br J Haematol. Br J Haematol. 2005;129(1):93-100.

33. Gerritsen HE, Turecek PL, Schwarz HP, et al. Assay of von Willebrand factor (vWF)-cleaving protease based on decreased collagen binding affinity of degraded vWF: a tool for the diagnosis of thrombotic thrombocytopenic purpura (TTP) Thromb Haemost. Thromb Haemost. 1999;82(5):1386-9.

34. Rick ME, Moll S, Taylor MA, et al. Clinical use of a rapid collagen binding assay for von Willebrand factor cleaving protease in patients with thrombotic thrombocytopenic purpura. Thromb Haemost. Thromb Haemost. 2002;88(4):598-604.

35. Bohm M, Vigh T, Scharrer I. Evaluation and clinical application of a new method for measuring activity of von Willebrand factor-cleaving metalloprotease (ADAMTS13) Ann Hematol. Ann Hematol. 2002;81(8):430-5.

36. Whitelock JL, Nolasco L, Bernardo A, et al. ADAMTS-13 activity in plasma is rapidly measured by a new ELISA method that uses recombinant VWF-A2 domain as substrate. J Thromb Haemost. 2004;2(3):485-91.

37. Rieger M, Mannucce P, Kremer Hovinga JA, et al. ADAMTS13 autoantibodies in patients with thrombotic microangiopathies and other immunomediated diseases. Blood. Blood. 2005;106(4):1262-7.

38. Petrović D, Čanović P, Mijailović Ž, Popovska-Jovičić B, Jaćović S. Hemolitičko-uremijski sindrom: etiopatogeneza, dijagnostika i osnovni principi lečenja. Med Čas 2015; 49(2):(in print).

39. Díaz-Cremades J, Fernández-Fuertes F, Ruano JA et al. Concurrent thrombotic thrombocytopenic purpura and antiphospholipid syndrome: a rare and severe clinical combination. Br J Haematol. 2009;147(4):584-5.

40. Ahmed I, Majeed A, Powell R. Heparin induced thrombocytopenia: diagnosis and management update. Postgrad Med J. 2007;83(983):575-82.

41. McCrae KR. Thrombocytopenia in pregnancy. Hematology Am Soc Hematol Educ Program. 2010; 2010(1):397-402. 
42. Soucemarianadin M, Benhamou Y, Delmas Y, et al. Twice-daily therapeutical plasma exchange-based salvage therapy in severe autoimmune thrombotic thrombocytopenic purpura: the French TMA Reference Center experience. Eur J Haematol. 2015 Nov 26. [Epub ahead of print]

43. Scully M, Hunt BJ, Benjamin S, et al. Guidelines on the diagnosis and management of thrombotic thrombocytopenic purpura and other thrombotic microangiopathies. Br J Haematol. 2012;158(3):323-35.

44. Balduini CL, Gugliotta L, Luppi M, et al; Italian TTP Study Group. High versus standard dose methylprednisolone in the acute phase of idiopathic thrombotic thrombocytopenic purpura: a randomized study. Ann Hematol. 2010;89(6):591-596.

45. Scully M, McDonald V, Cavenagh J, et al. A phase 2 study of the safety and efficacy of rituximab with plasma exchange in acute acquired thrombotic thrombocytopenic purpura. Blood. 2011;118(7):1746-1753.

46. Froissart A, Buffet M, Veyradier A, et al. Efficacy and safety of first-line rituximab in severe, acquired thrombotic thrombocytopenic purpura with a suboptimal response to plasma exchange. Experience of the French Thrombotic Microangiopathies Reference Center. Crit Care Med. 2012;40(1):104-11.

47. Scully M, Cohen H, Cavenagh J, et al. Remission in acute refractory and relapsing thrombotic thrombocytopenic purpura following rituximab is associated with a reduction in IgG antibodies to ADAMTS-13. Br J Haematol. 2007;136(3):451-61.

48. Jasti $\mathrm{S}$, Coyle T, Gentile T, et al. Rituximab as an adjunct to plasma exchange in TTP: a report of 12 cases and review of literature. J Clin Apher. 2008;23(5):151-6.

49. Ling HT, Field JJ, Blinder MA. Sustained response with rituximab in patients with thrombotic thrombocytopenic purpura: a report of 13 cases and review of the literature. Am J Hematol. 2009;84(7):418-21.

50. Chemnitz JM, Uener J, Hallek M, Scheid C. Long-term follow-up of idiopathic thrombotic thrombocytopenic purpura treated with rituximab. Ann Hematol. 2010;89(10):1029-33.
51. de la Rubia J, Moscardó F, Gómez MJ, et al. Efficacy and safety of rituximab in adult patients with idiopathic relapsing or refractory thrombotic thrombocytopenic purpura: results of a Spanish multicenter study. Transfus Apher Sci. 2010;43(3):299-303.

52. Goyal J, Adamski J, Lima JL, Marques MB. Relapses of thrombotic thrombocytopenic purpura after treatment with rituximab. J Clin Apher. 2013;28(6):390-4.

53. Yates S, Matevosyan K, Rutherford C, et al. Bortezomib for chronic relapsing thrombotic thrombocytopenic purpura: a case report. Transfusion. 2014;54(8):2064-7.

54. Shortt J, Oh DH, Opat SS. ADAMTS13 antibody depletion by bortezomib in thrombotic thrombocytopenic purpura. N Engl J Med. 2013;368(1):90-2.

55. Patel PP, Becker J, Freyer C, et al. Rituximab-refractory thrombotic thrombocytopenic purpura responsive to intravenous but not subcutaneous bortezomib. Transfusion. 2016 Jan 18. [Epub ahead of print]

56. Hie M, Gay J, Galicier L, et al. Preemptive rituximab infusions after remission efficiently prevent relapses in acquired thrombotic thrombocytopenic purpura. Blood. 2014;124(2):204-10.

57. Westwood JP, Webster H, McGuckin S, et al. Rituximab for thrombotic thrombocytopenic purpura: benefit of early administration during acute episodes and use of prophylaxis to prevent relapse. J Thromb Haemost. 2013;11(3):481-90.

58. Plaimauer B, Kremer Hovinga JA, Juno C, et al. Recombinant ADAMTS13 normalizes von Willebrand factorcleaving activity in plasma of acquired TTP patients by overriding inhibitory antibodies. J Thromb Haemost. 2011;9(5):936-944.

59. Callewaert F, Roodt J, Ulrichts H, et al. Evaluation of efficacy and safety of the anti-VWF Nanobody ALX0681 in a preclinical baboon model of acquired thrombotic thrombocytopenic purpura. Blood. 2012;120(17): 3603-3610.

60. Ulrichts H, Silence K, Schoolmeester A, et al. Antithrombotic drug candidate ALX-0081 shows superior preclinical efficacy and safety compared with currently marketed antiplatelet drugs. Blood. 2011;118(3):757-765. 